\title{
Correction to: Esogastro-Pleuro-Bronchial Fistula: An Unusual Complication After Sleeve Gastrectomy
}

\author{
Jesus Badia-Closa ${ }^{1} \cdot$ Alexis Luna $^{1} \cdot$ Sandra Montmany $^{1} \cdot$ Pere Rebasa $^{1} \cdot$ Salvador Navarro ${ }^{1}$ \\ Published online: 19 November 2020 \\ (C) Springer Science+Business Media, LLC, part of Springer Nature 2020
}

\section{Correction to: Obesity Surgery \\ https://doi.org/10.1007/s11695-020-04701-2}

Due to a Production error Figs. 1 and 2 were omitted from the original article. The original article has been revised.

Publisher's Note Springer Nature remains neutral with regard to jurisdictional claims in published maps and institutional affiliations.

The online version of the original article can be found at https://doi.org/ 10.1007/s11695-020-04701-2

Jesus Badia-Closa xus@badia.me

1 Gastrointestinal Unit, Department of General and Digestive Surgery, Parc Taulí University Hospital, Universitat Autònoma de Barcelona (UAB), Parc Taulí s/n, 08208, Sabadell, Barcelona, Spain 